\title{
An intermediate temperature fuel cell based on composite electrolyte of carbonate and doped barium cerate with $\mathrm{SrFe}_{0.7} \mathrm{Mn}_{0.2} \mathrm{Moo.1}_{0.1} \mathrm{O}_{3-\delta}$ cathode
}

Lei Zhang, Rong Lan and Shanwen Tao*

Department of Chemical \& Process Engineering, University of Strathclyde, Glasgow G1 1XJ, UK

\begin{abstract}
$\mathrm{BaCeO}_{3}$-based proton conductor $\mathrm{BaCe}_{0.5} \mathrm{Zr}_{0.3} \mathrm{Y}_{0.16} \mathrm{Zn}_{0.04} \mathrm{O}_{3-\delta}(\mathrm{BCZYZn})$ was adopted as a part of the oxide-carbonate composite electrolyte. The total ionic conductivity of BCZYZn-carbonate composite is $0.28 \mathrm{~S} \mathrm{~cm}^{-1}$ at $500{ }^{\circ} \mathrm{C}$. Perovskite oxide $\mathrm{SrFe}_{0.7} \mathrm{Mn}_{0.2} \mathrm{Moo}_{0.1} \mathrm{O}_{3-\delta}$ was developed and used as cathode. It was found that $\mathrm{SrFe}_{0.7} \mathrm{Mn}_{0.2} \mathrm{Mo}_{0.1} \mathrm{O}_{3-\delta}$ exhibits a primitive cubic structure with space group $\operatorname{Pm} \overline{3} \mathrm{~m}(221) ; a=3.8790(1) \AA, V=58.364(1) \AA^{3}$. The electrical conductivity of $\mathrm{SrFe}_{0.7} \mathrm{Mn}_{0.2} \mathrm{Mo}_{0.1} \mathrm{O}_{3-\delta}$ is $15-26 \mathrm{~S} \mathrm{~cm}^{-1}$ in the temperature range $400-700{ }^{\circ} \mathrm{C}$ measured by d.c. method. Single cell with BCZYZn-carbonate composite electrolyte and $\mathrm{SrFe}_{0.7} \mathrm{Mn}_{0.2} \mathrm{Mo}_{0.1} \mathrm{O}_{3-\delta}$ cathode was fabricated and tested with humidified $\mathrm{H}_{2}(\sim 3 \mathrm{vol} \%$ $\mathrm{H}_{2} \mathrm{O}$ ) as fuel and air as oxidant. A similar configuration cell with lithiated $\mathrm{NiO}$ cathode was also constructed for comparison. It was found that neither $\mathrm{BaCe}_{0.5} \mathrm{Zr}_{0.3} \mathrm{Y}_{0.16} \mathrm{Zn}_{0.04} \mathrm{O}_{3-\delta}$ nor $\mathrm{SrFe}_{0.7} \mathrm{Mn}_{0.2} \mathrm{Mo}_{0.1} \mathrm{O}_{3-\delta}$ is chemically compatible with $(\mathrm{Li}, \mathrm{Na})_{2} \mathrm{CO}_{3}$. The fuel cell performance is not as good as those based on doped ceria-carbonate electrolytes.
\end{abstract}

Keywords: oxide-carbonate composite, conductivity, perovskite, cathode, fuel cell.

\footnotetext{
* Corresponding author.

Department of Chemical and Process Engineering University of Strathclyde
} 
Glasgow G1 1XJ, UK

E-mail:shanwen.tao@strath.ac.uk 


\section{Introduction}

The current research trend for solid oxide fuel cells is to bring down the working temperature from $800-1000{ }^{\circ} \mathrm{C}$ to $400-600{ }^{\circ} \mathrm{C}$, in order to reduce the fabrication cost and improve the durability. Recently, doped-ceria and carbonate composite materials have drawn increasing attentions for their exceptional high conductivity at temperature $400-600{ }^{\circ} \mathrm{C}$ [1-10]. The composite normally employ doped-ceria oxide as substrate matrix to allow the carbonates distributed inside. Ionic conductivity of $\sim 0.1$ $\mathrm{S} \mathrm{cm}^{-1}$ can be reached at temperature close to the melting point of carbonates [3] and excellent cell performance with maximum power density of $\sim 1 \mathrm{~W} \mathrm{~cm}{ }^{-2}$ has been achieved [11]. Besides $\mathrm{O}^{2-}$ conducting doped ceria, $\mathrm{LiAlO}_{2}$ was also mixed with $(\mathrm{Li} / \mathrm{Na})_{2} \mathrm{CO}_{3}$ to form a composite electrolyte and a maximum output power density of $466 \mathrm{~mW} \mathrm{~cm}^{-2}$ has been achieved at $650{ }^{\circ} \mathrm{C}[12]$.

Proton-conducting oxides such as doped barium cerates have been widely studied as electrolytes for SOFCs [13-17]. This perovskite-type oxide shows mixed proton and oxide-ion conductivity [16] at intermediate temperature in humid atmospheres and its proton conductivity can be significantly enhanced by various rare earth ions doping [18-22]. Unfortunately, most doped barium cerates are not stable in the presence of $\mathrm{CO}_{2}$ and the stability has been improved when some cerium ions at $\mathrm{B}$-sites were replaced by zirconium ions [20, 23]. Zhu and Schober et al. reported to mix proton conductor $\mathrm{BaCe}_{0.8} \mathrm{Y}_{0.2} \mathrm{O}_{3-\delta}$ or $\mathrm{BaCe}_{0.9} \mathrm{Y}_{0.1} \mathrm{O}_{3-\delta}$ with carbonates to form composite materials $[24,25]$. Huang et al. reported the conductivity of $\mathrm{BaZr}_{0.8} \mathrm{Y}_{0.2} \mathrm{O}_{3-\delta}$ $\left(\mathrm{Li}_{0.62} \mathrm{~K}_{0.38}\right)_{2} \mathrm{CO}_{3}$ composite electrolyte and a power density of $114 \mathrm{~mW} / \mathrm{cm}^{2}$ has been achieved for a $\mathrm{H}_{2} /$ air fuel cell based on this composite electrolyte[26]. In these proton conducting oxides, $\mathrm{BaCe}_{0.5} \mathrm{Zr}_{0.3} \mathrm{Y}_{0.16} \mathrm{Zn}_{0.04} \mathrm{O}_{3-\delta}(\mathrm{BCZYZn})$ exhibits conductivity over $10 \mathrm{mS} \mathrm{cm}^{-1}$ above $600{ }^{\circ} \mathrm{C}$ in wet $5 \% \mathrm{H}_{2}$ [20]. This oxide is also stable in pure $\mathrm{CO}_{2}$ at high temperatures. Introduction of a small amount of zinc at B-site can significantly reduce the sintering temperature of $\mathrm{BaZrO}_{3}$-based oxides. To the best of our 
knowledge, there is no report on using stable proton-conducting oxide BCZYZn as a part of an oxide-carbonate composite electrolyte. Apart from the electrolyte, the cell performance is greatly affected by the property of cathode. In our previous study, we demonstrated that traditional lithiated $\mathrm{NiO}$ cathode used for molten carbonate fuel cells (MCFCs) suffer the same problem when being used for ceria-carbonate composite fuel cell [7]. Lithiation $\mathrm{NiO}$ could gradually diffuse into the composite electrolyte and cause performance degradation. Therefore, it is well worth to explore new cathode material for this kind of composite electrolyte. It has been demonstrated that stable fuel cell performance has been achieved wen perovskite oxide $\mathrm{Sm}_{0.5} \mathrm{Sr}_{0.5} \mathrm{Fe}_{0.8} \mathrm{Cu}_{0.2} \mathrm{O}_{3-\delta}$ was used as cathode for fuel cells based on oxide-carbonate composite electrolyte[27]. In this work, a new perovskite oxide $\mathrm{SrFe}_{0.7} \mathrm{Mn}_{0.2} \mathrm{Mo}_{0.1} \mathrm{O}_{3-\delta}$ was also synthesized and used as the cathode in a fuel cell based on BCZYZn-carbonate composite electrolyte. For comparison, single cells were fabricated by one-step co-pressing-sintering process with $\mathrm{SrFe}_{0.7} \mathrm{Mn}_{0.2} \mathrm{Mo}_{0.1} \mathrm{O}_{3-\delta}$ and lithiated $\mathrm{NiO}$ as cathode respectively. Humidified $\mathrm{H}_{2}\left(\sim 3 \mathrm{vol} \% \mathrm{H}_{2} \mathrm{O}\right)$ was used as fuel and air as oxidant at the cathode.

\section{Experimental}

$\mathrm{BaCe}_{0.5} \mathrm{Zr}_{0.3} \mathrm{Y}_{0.16} \mathrm{Zn}_{0.04} \mathrm{O}_{3-\delta} \quad(\mathrm{BCZYZn})$ was synthesized by solid state reaction combined with impregnation method. Stoichiometric quantities of $\mathrm{BaCO}_{3}, \mathrm{CeO}_{2}$, $\mathrm{ZrO}_{2}$ and $\mathrm{Y}_{2} \mathrm{O}_{3}$ were ball-milled for 2 hours in 2-propanol and subsequently dried at $50{ }^{\circ} \mathrm{C}$ for 24 hours. The powders were calcined at $1200{ }^{\circ} \mathrm{C}$ for 2 hours and then ball-milled again for 2 hours and dried. Zn was introduced by impregnation method. Calculated amount of $\mathrm{Zn}\left(\mathrm{NO}_{3}\right)_{2} \cdot 6 \mathrm{H}_{2} \mathrm{O}$ was dissolved in deionized water and the obtained dried powders were added to the solution under stirring. The slurry was dried at $80{ }^{\circ} \mathrm{C}$ in air for 24 hours and fired at $1300{ }^{\circ} \mathrm{C}$ for 5 hours to obtain single phase BCZYZn. The composite electrolyte was made by mixing the BCZYZn powders and carbonate salts $\left(53 / 47 \mathrm{~mol} \%, \mathrm{Li}_{2} \mathrm{CO}_{3} / \mathrm{Na}_{2} \mathrm{CO}_{3}\right)$ at weight ratio of $60 / 40$ then fired at $700{ }^{\circ} \mathrm{C}$ for 1 hour before subsequently being quenched in air. 
$\mathrm{SrFe}_{0.7} \mathrm{Mn}_{0.2} \mathrm{Mo}_{0.1} \mathrm{O}_{3-\delta}$ (SFMMo) cathode was prepared by glycine-nitrate combustion process. $\mathrm{Sr}\left(\mathrm{NO}_{3}\right)_{2}, \mathrm{Fe}\left(\mathrm{NO}_{3}\right)_{3} \cdot 9 \mathrm{H}_{2} \mathrm{O},\left(\mathrm{CH}_{3} \mathrm{CO}_{2}\right)_{2} \mathrm{Mn} \cdot 4 \mathrm{H}_{2} \mathrm{O}$ and $\left(\mathrm{NH}_{4}\right)_{6} \mathrm{Mo}_{7} \mathrm{O}_{24} \cdot 4 \mathrm{H}_{2} \mathrm{O}$ were used as metal precursors and dissolved in deionized water. The solution was heated under continually stirring and glycine $\left(\mathrm{NH}_{2} \mathrm{CH}_{2} \mathrm{COOH}\right)$ was added at a glycine/metal molar ratio of $2: 1$. The solution was further heated until spontaneous ignition occurred. The as-prepared powders were subsequently calcined at $1000{ }^{\circ} \mathrm{C}$ for 3 hours to obtain single phase SFMMo. The powders were pressed into pellets with a diameter of $\sim 13 \mathrm{~mm}$ and thickness $\sim 2 \mathrm{~mm}$ then fired at $1300{ }^{\circ} \mathrm{C}$ for 4 hours. Silver electrode was coated on both sides of the fired pellets for conductivity measurement. Lithiated $\mathrm{NiO}$ with composition $\mathrm{Li}_{0.3} \mathrm{Ni}_{0.7} \mathrm{O}$ was synthesized by the same method as described elsewhere [28].

$\mathrm{X}$-ray diffraction (XRD) data were conducted at room temperature using a Panalytical X'Pert Pro diffractometer with Ni-filtered $\mathrm{Cu} K \alpha$ radiation using $40 \mathrm{kV}$ and $40 \mathrm{~mA}(\lambda$ $=1.5405 \AA$ ), fitted with a X'Celerator detector. Absolute scans were recorded in the $2 \theta$ range $5-100^{\circ}$ with a step size of $0.0167^{\circ}$.

For conductivity measurement, the as-prepared composite electrolyte was pressed into pellets with diameter of $\sim 13 \mathrm{~mm}$ and thickness of $\sim 2 \mathrm{~mm}$, then fired at $600{ }^{\circ} \mathrm{C}$ for 30 minute. After coated a layer of silver paste on both sides, the conductivity was measured by a.c. impedance method. AC impedance spectroscopy and fuel cell performances were tested by a Solartron 1250 Frequency Response Analyser coupled to a 1287A Electrochemical Interface using CorrWare/CorrView software. Electrical conductivity of SFMMo was measured by a pseudo-four-probe d.c. method using a Solartron 1470 at constant current mode.

Single cell was fabricated by dry-pressing anode (NiO/electrolyte at 50/50wt\%), electrolyte and cathode (electrolyte/SFMMo at 50/50wt\% with starch) at simple one-step under $300 \mathrm{MPa}$. The cell was sintered at $550{ }^{\circ} \mathrm{C}$ for 1 hour with an effective 
working area of $0.5 \mathrm{~cm}^{-2}$. The thickness of anode, electrolyte and cathode was $0.3 \mathrm{~mm}$, $1 \mathrm{~mm}$ and $0.2 \mathrm{~mm}$, respectively and this was carefully controlled by weighing the amounts of powders added. Silver paste was used on each side of the electrodes to improve electrical contact. As silver itself is a good cathode for intermediate temperature fuel cells, it cannot be ruled out that the fuel cell performance could be improved due to the use of silver as current collector. Wet hydrogen $\left(\sim 3\right.$ vol\% $\left.\mathrm{H}_{2} \mathrm{O}\right)$ with a flow rate of $100 \mathrm{ml} \mathrm{min}^{-1}$ was supplied as fuel while the cathode side was open to air. The fuel cell measurement set-up has been reported elsewhere [7].

\section{Results and discussion}

Fig. 1a shows the XRD patterns of $\mathrm{BaCe}_{0.5} \mathrm{Zr}_{0.3} \mathrm{Y}_{0.16} \mathrm{Zn}_{0.04} \mathrm{O}_{3-\delta}(\mathrm{BCZYZn})$ and BCZYZn-carbonate composite. BCZYZn expresses single phase with cubic structure. The lattice parameter was calculated at $a=4.3273$ (1) $\AA$. The conductivity of pure $\mathrm{BaCe}_{0.5} \mathrm{Zr}_{0.3} \mathrm{Y}_{0.16} \mathrm{Zn}_{0.04} \mathrm{O}_{3-\delta}$ and $\mathrm{BaCe}_{0.5} \mathrm{Zr}_{0.3} \mathrm{Y}_{0.16} \mathrm{Zn}_{0.04} \mathrm{O}_{3-\delta}-(\mathrm{Li}, \mathrm{Na})_{2} \mathrm{CO}_{3}$ composite is shown in Fig. 2. The conductivity of pure $\mathrm{BaCe}_{0.5} \mathrm{Zr}_{0.3} \mathrm{Y}_{0.16} \mathrm{Zn}_{0.04} \mathrm{O}_{3-\delta}$ gradually increased at higher temperatures and reached $0.01 \mathrm{~S} \mathrm{~cm}^{-1}$ at $700{ }^{\circ} \mathrm{C}$. For the composite, the conductivity is in the range of $10^{-6} \mathrm{~S} \mathrm{~cm}^{-1}$ at $300{ }^{\circ} \mathrm{C}$ but reached $0.28 \mathrm{~S}$ $\mathrm{cm}^{-1}$ at $500{ }^{\circ} \mathrm{C}$. At $400{ }^{\circ} \mathrm{C}$, the total conductivity of the composite is comparable to pure BCZYZn but the composite exhibits much higher conductivity at a temperature above $400{ }^{\circ} \mathrm{C}$ which could be related to the defects at the oxide/carbonate interface $[29,30]$. On the other hand, when the temperature approaches the melting point, the carbonates become 'soft'. Therefore the mobility of various ions $\left(\mathrm{Na}^{+}, \mathrm{Li}^{+}, \mathrm{H}^{+}\right.$, and $\mathrm{CO}_{3}{ }^{2-}$ ) was significantly increased, leading to high ionic conductivity. This phenomenon of sharp increase of conductivity has been observed in our precious study of ceria-carbonate composites $[6,7]$; however, the conductivity of BCZYZn-carbonate composite is slightly higher compared to $\mathrm{Ce}_{0.8} \mathrm{Gd}_{0.05} \mathrm{Y}_{0.15} \mathrm{O}_{1.9}$ (GYDC) carbonate composite $\left(0.18 \mathrm{~S} \mathrm{~cm}^{-1}\right.$ at $\left.500{ }^{\circ} \mathrm{C}\right)[6]$.

Single phase of $\mathrm{SrFe}_{0.7} \mathrm{Mn}_{0.3} \mathrm{Mo}_{0.1} \mathrm{O}_{3-\delta}$ was obtained when the sample was fired at $1100{ }^{\circ} \mathrm{C}$. To obtain high quality refinement, XRD pattern from well-crystallized sample fired at $1300{ }^{\circ} \mathrm{C}$ was used for Rietveld refinement using software GSAS [31]. 
It was found that $\mathrm{SrFe}_{0.7} \mathrm{Mn}_{0.3} \mathrm{Mo}_{0.1} \mathrm{O}_{3-\delta}$ exhibit a primitive cubic structure with space group $\operatorname{Pm} \overline{3} \mathrm{~m}(221) ; a=3.8790(1) \AA, V=58.364(1) \AA^{3}$. This is the same structure as reduced $\mathrm{SrMn}_{0.5} \mathrm{Nb}_{0.5} \mathrm{O}_{2.875}$ [32]. In this structure, $\mathrm{Fe}, \mathrm{Mn}$ and Mo ions are randomly distributed at the B-site. The refinement also indicates that the occupancy of oxygen is 0.97 which means that the obtained $\mathrm{SrFe}_{0.7} \mathrm{Mn}_{0.3} \mathrm{Mo}_{0.1} \mathrm{O}_{3-\delta}$ is an oxygen deficient oxide. It should also be noted that XRD is not sensitive to light atom such as oxygen. Neutron diffraction is necessary for more accurate determination. The XRD pattern of $\mathrm{SrFe}_{0.7} \mathrm{Mn}_{0.3} \mathrm{Mo}_{0.1} \mathrm{O}_{3-\delta}$ is shown in Fig. 3 and refined lattice parameters are listed in Table 1.

Fig. 4 shows the d.c. conductivity of $\mathrm{SrFe}_{0.7} \mathrm{Mnn}_{0.3} \mathrm{Moo}_{0.1} \mathrm{O}_{3-\delta}$ between 40 and $700{ }^{\circ} \mathrm{C}$. The total conductivity was $15-26 \mathrm{~S} \mathrm{~cm}^{-1}$ between $400-700{ }^{\circ} \mathrm{C}$ which is adequate to be used as cathode materials for fuel cells.

Single cells with SFMMo cathode were fabricated by co-pressing the tri-layer of anode, electrolyte and cathode at single step and fired at $550{ }^{\circ} \mathrm{C}$ for 1 hour. The cell performance was evaluated using $\mathrm{H}_{2}$ as fuel, air as oxidant. The results are shown in Fig. 5a. Open circuit voltages (OCVs) of 1.06, 1.02 and $1.01 \mathrm{~V}$ were obtained at temperatures 500,525 and $550{ }^{\circ} \mathrm{C}$ respectively. These OCVs are very close to the theoretical value and comparable to the result of fuel cells based on ceria-carbonate composite $[6,7]$, indicating that the electrolyte was gas tight. The maximum power densities were 62,102 and $160 \mathrm{~mW} \mathrm{~cm}{ }^{-2}$ at 500,525 , and $550{ }^{\circ} \mathrm{C}$, respectively. These performances are comparable to the results of other pervoskite oxides such as $\mathrm{La}_{0.8} \mathrm{Sr}_{0.2} \mathrm{MnO}_{3}$ (LSM) and $\mathrm{La}_{0.6} \mathrm{Sr}_{0.4} \mathrm{Co}_{0.2} \mathrm{Fe}_{0.8} \mathrm{O}_{3}$ (LSCF) used as cathode for the ceria-carbonate composite based fuel cells [33]. The performance is lower than those with ceria-carbonate composite as electrolytes. The impedance spectra of the cell under open circuit conditions were measured at temperature $500-550{ }^{\circ} \mathrm{C}$ as shown in Fig. 5b. The series resistances $\mathrm{R}_{\mathrm{S}}$ (intercept with real axis at high frequency) are 0.71, 0.56 and $0.36 \Omega \mathrm{cm}^{2}$ at 500,525 and $550{ }^{\circ} \mathrm{C}$ respectively. The total resistances $\mathrm{R}_{\mathrm{t}}$ (intercept with real axis at low frequency) are 3.48, 3.29 and $3.05 \Omega \mathrm{cm}^{2}$ at 500,525 
and $550{ }^{\circ} \mathrm{C}$ respectively. Therefore, the electrode polarization resistances $\left(\mathrm{R}_{\mathrm{p}}\right)$ of the cell are considered as the difference between $\mathrm{R}_{\mathrm{t}}$ and $\mathrm{R}_{\mathrm{s}}$, which are 2.77, 2.73 and 2.69 $\Omega \mathrm{cm}^{2}$ at 500,525 and $550{ }^{\circ} \mathrm{C}$. Slightly higher polarization resistance was observed at $525{ }^{\circ} \mathrm{C}$ which might be related to microstructure change at the electrodes due to the melting and/or diffusion of molten carbonate components. Further investigation is required. Clearly, the major polarization resistance is from the electrode and/or electrode-electrolyte interface.

For comparison, a similar configuration single cell was also fabricated with $\mathrm{Li}_{0.3} \mathrm{Ni}_{0.7} \mathrm{O}_{\mathrm{y}}$ cathode and cell performance is shown in Fig. 6a. OCVs of 1.09, 1.03 and $1.01 \mathrm{~V}$ were observed at 500,525 and $550{ }^{\circ} \mathrm{C}$ respectively. The maximum power density at $550{ }^{\circ} \mathrm{C}$ is $183 \mathrm{~mW} \mathrm{~cm}{ }^{-2}$ which is slightly higher than that for the cell with SFMMo cathode. Various polarization resistances are showed in Fig. 6b. Series resistance $R_{s}$ were $0.23,0.17$ and $0.15 \Omega \mathrm{cm}^{2}$ while the corresponding $R_{p}$ were 1.69, 1.21 and $0.87 \Omega \mathrm{cm}^{2}$ at 500,525 and $550{ }^{\circ} \mathrm{C}$ respectively. The resistances are comparable to the values when GYDC was used as part of the oxide-carbonate composite [7], due to the high conductivity of BCZYZn-carbonate composite at lower temperature. The large electrode polarization could be related to the microstructure and composition of electrodes and further optimization is required.

After the fuel cell test, some reactions between BCZYZn and carbonates were observed as shown in Fig. 1b. $\mathrm{BaCO}_{3}, \mathrm{Ba}\left(\mathrm{Ce}_{x} \mathrm{Zr}_{1-x}\right) \mathrm{O}_{3}$ and $\mathrm{CeO}_{2}$ were formed in the composite. As $\mathrm{BCZYZn}$ is stable in pure $\mathrm{CO}_{2}$, for formation of $\mathrm{BaCO}_{3}$ is believed due to the reaction between $\mathrm{BCZYZn}$ and carbonate with the leaching of $\mathrm{CeO}_{2}$. The formed $\mathrm{BaCO}_{3}$ may affect the catalytic activity of electrode leading to higher polarization resistance and lower fuel cell performance. The ionic conductivity of the BaCZYZn-carbonate was not affected as the series resistance is about $0.2 \Omega \mathrm{cm}^{2}$ around $525^{\circ} \mathrm{C}$.

In order to further identify the reason for the different fuel cell performance when $\mathrm{SrFe}_{0.7} \mathrm{Mn}_{0.3} \mathrm{Mo}_{0.1} \mathrm{O}_{3-\delta}$ and $\mathrm{Li}_{0.3} \mathrm{Ni}_{0.7} \mathrm{O}_{\mathrm{y}}$ was used as the cathode respectively, the 
chemical compatibility between the electrolyte and SFMMO cathode was carried out by XRD study. As the different components in the composite electrolyte, BCZYZn and $(\mathrm{Li}, \mathrm{Na})_{2} \mathrm{CO}_{3}$ react with each other (Fig. 1b), SFMMO was mixted with BCZYZn or $(\mathrm{Li}, \mathrm{Na})_{2} \mathrm{CO}_{3}$ separately with a weight ratio of 50/50. After firing the SFMMO/BCZYZn mixture at $600{ }^{\circ} \mathrm{C}$ for 10 hours, it was found that the two oxides are compatible with each other (Fig. 7b). However, after firing the $\mathrm{SFMMO} /(\mathrm{Li}, \mathrm{Na})_{2} \mathrm{CO}_{3}$ mixture at the same condition, the room temperature XRD pattern indicates that the main phase is $\mathrm{SrCO}_{3}$ (PDF Card No. 01-074-1491) (Fig. 7c). There are two unidentified peaks. This experiment indicates that SFMMO is not chemically compatible with the mixed carbonate. In SFMMO, A-sites are only occupied by alkaline earth element strontium rather than doped with rare earth elements such as Sm, La etc., therefore the activity of strontium is very high thus easy to react with carbonates to form stable $\mathrm{SrCO}_{3}$. Partial replacement of $\mathrm{Sr}$ by rare earth element may make this perovskite oxide compatible with carbonates. Diffraction peaks for oxides containing $\mathrm{Fe}, \mathrm{Mn}$, Mo were not observed, possibly in amorphous state. The reaction between SFMMO cathode and mixed carbonate may cause the lower fuel cell performance comparing to that with $\mathrm{Li}_{0.3} \mathrm{Ni}_{0.7} \mathrm{O}_{\mathrm{y}}$ cathode.

\section{Conclusion}

$\mathrm{BaCeO}_{3}$-based proton conductor $\mathrm{BaCe}_{0.5} \mathrm{Zr}_{0.3} \mathrm{Y}_{0.16} \mathrm{Zn}_{0.04} \mathrm{O}_{3-\delta}(\mathrm{BCZYZn})$ was employed as part of the oxide-carbonate composite electrolyte. New perovskite oxide $\mathrm{SrFe}_{0.7} \mathrm{Mn}_{0.2} \mathrm{Mo}_{0.1} \mathrm{O}_{3-\delta}$ (SFMMo) was synthesized and used as cathode for the composite fuel cell. It was found that $\mathrm{SrFe}_{0.7} \mathrm{Mn}_{0.2} \mathrm{Mo}_{0.1} \mathrm{O}_{3-\delta}$ exhibits a primitive cubic

structure with space group $\operatorname{Pm} \overline{3} \mathrm{~m}(221) ; a=3.8790(1) \AA, V=58.364(1) \AA^{3}$. The electrical conductivity of SFMMo is $15-26 \mathrm{~S} \mathrm{~cm}^{-1}$ in the temperature range 400-700 ${ }^{\circ} \mathrm{C}$. Single cells with SFMMo and lithiated NiO cathodes were tested and compared. It was found that $\mathrm{BCZYZn}$ and carbonate react with each to form $\mathrm{BaCO}_{3}$ and new oxides during the fuel cell measurements. The chemical compatibility between $\mathrm{BaZr}_{0.8} \mathrm{Y}_{0.2} \mathrm{O}_{3-\delta}$ and $\left(\mathrm{Li}_{0.62} \mathrm{~K}_{0.38}\right)_{2} \mathrm{CO}_{3}$ is good but the fuel cell performance is not ideal[26]. The fuel cell performance based on either BCZYZn-carbonate or 
$\mathrm{BaZr}_{0.8} \mathrm{Y}_{0.2} \mathrm{O}_{3-\delta}-\left(\mathrm{Li}_{0.62} \mathrm{~K}_{0.38}\right)_{2} \mathrm{CO}_{3}$ composite electrolyte is not as good as those based on doped ceria-carbonate composite electrolytes. The chemical reaction between $\mathrm{BCZYZn}$ and $(\mathrm{Li}, \mathrm{Na})_{2} \mathrm{CO}_{3}$ in the electrolyte indicates BCZYZn-( $\left.\mathrm{Li}, \mathrm{Na}\right)_{2} \mathrm{CO}_{3}$ composite is not a good electrolyte for intermediate temperature fuel cells. So far composite electrolytes based on doped ceria are still the best choice.

\section{Acknowledgements}

We thank EPSRC for funding. One of the authors (Zhang) thanks ScotCHEM for a $\mathrm{PhD}$ studentship. 


\section{References}

[1] B. Zhu, X. Liu, P. Zhou, X. Yang, Z. Zhu, W. Zhu, Innovative solid carbonate-ceria composite electrolyte fuel cells, Electrochemistry communications, 3 (2001) 566-571.

[2] B. Zhu, Functional ceria-salt-composite materials for advanced ITSOFC applications, Journal of Power Sources, 114 (2003) 1-9.

[3] A. Bodén, J. Di, C. Lagergren, G. Lindbergh, C.Y. Wang, Conductivity of SDC and (Li/Na)2CO3 composite electrolytes in reducing and oxidising atmospheres, Journal of Power Sources, 172 (2007) 520-529.

[4] J. Huang, Z. Mao, Z. Liu, C. Wang, Performance of fuel cells with proton-conducting ceria-based composite electrolyte and nickel-based electrodes, Journal of Power Sources, 175 (2008) 238-243.

[5] Y. Ma, X. Wang, S. Li, M.S. Toprak, B. Zhu, M. Muhammed, Samarium Doped Ceria Nanowires: Novel Synthesis and Application in Low Temperature Solid Oxide Fuel Cells, Advanced Materials, 22 (2010) 1640-1644.

[6] L. Zhang, R. Lan, X.X. Xu, S.W. Tao, Y.Z. Jiang, A. Kraft, A high performance intermediate temperature fuel cell based on a thick oxide-carbonate electrolyte, Journal of Power Sources, 194 (2009) 967-971.

[7] L. Zhang, R. Lan, C.T.G. Petit, S.W. Tao, Durability study of an intermediate temperature fuel cell based on an oxide-carbonate composite electrolyte, International Journal of Hydrogen Energy, 35 (2010) 6934-6940.

[8] A.S.V. Ferreira, C.M.C. Soares, F. Figueiredo, F.M.B. Marques, Intrinsic and extrinsic compositional effects in ceria/carbonate composite electrolytes for fuel cells, International Journal of Hydrogen Energy, 36 (2011) 3704-3711.

[9] L. Jia, Y. Tian, Q. Liu, C. Xia, J. Yu, Z. Wang, Y. Zhao, Y. Li, A direct carbon fuel cell with (molten carbonate)/(doped ceria) composite electrolyte, Journal of Power Sources, 195 (2010) 5581-5586.

[10] B. Zhu, L. Fan, P. Lund, Breakthrough fuel cell technology using ceria-based multi-functional nanocomposites, Applied Energy, 106 (2013) 163-175.

[11] J. Huang, Z. Mao, Z. Liu, C. Wang, Performance of fuel cells with proton-conducting ceria-based composite electrolyte and nickel-based electrodes, J. Power Sources, 175 (2008) 238-243.

[12] S. Li, X.D. Wang, B. Zhu, Novel ceramic fuel cell using non-ceria-based composites as electrolyte, Electrochem. Commun., 9 (2007) 2863-2866.

[13] K.D. Kreuer, Proton conductivity: materials and applications, Chemistry of Materials, 8 (1996) 610-641.

[14] K. Kreuer, On the development of proton conducting materials for technological applications, Solid State Ionics, 97 (1997) 1-15.

[15] N. Bonanos, K. Knight, B. Ellis, Perovskite solid electrolytes: Structure, transport properties and fuel cell applications, Solid State Ionics, 79 (1995) 161-170.

[16] H. Iwahara, Proton conducting ceramics and their applications, Solid State Ionics, 86 (1996) 9-15.

[17] H. Iwahara, T. Esaka, H. Uchida, N. Maeda, PROTON CONDUCTION IN SINTERED OXIDES AND ITS APPLICATION TO STEAM ELECTROLYSIS FOR HYDROGEN-PRODUCTION, Solid State Ion., 3-4 (1981) 359-363.

[18] N. Bonanos, Transport properties and conduction mechanism in high-temperature protonic conductors, Solid State Ionics, 53 (1992) 967-974. 
[19] J. Wu, S. Webb, S. Brennan, S. Haile, Dopant site selectivity in BaCe0. 85M0. 15O3- by extended X-ray absorption fine structure, Journal of applied physics, 97 (2005) 054101-054101-054107.

[20] S.W. Tao, J.T.S. Irvine, A Stable, Easily Sintered Proton Conducting Oxide Electrolyte for Moderate Temperature Fuel Cells and Electrolyzers, Advanced Materials, 18 (2006) 1581-1584.

[21] C. Zuo, S. Zha, M. Liu, M. Hatano, M. Uchiyama, Ba (Zr 0.1 Ce 0.7 Y 0.2) O 3 - as an electrolyte for low-temperature solid-oxide fuel cells, Adv Mater, 18 (2006) 3318-3320.

[22] L. Yang, S. Wang, K. Blinn, M. Liu, Z. Liu, Z. Cheng, Enhanced sulfur and coking tolerance of a mixed ion conductor for SOFCs: BaZr (0.1) Ce (0.7) Y (0.2-x) Yb (x) O (3-delta), Science (New York, NY), 326 (2009) 126.

[23] L. Yang, C. Zuo, M. Liu, High-performance anode-supported Solid Oxide Fuel Cells based on Ba (Zr0. 1Ce0. 7Y0. 2) O3-[delta](BZCY) fabricated by a modified co-pressing process, Journal of Power Sources, 195 (2010) 1845-1848.

[24] B. Zhu, X. Liu, T. Schober, Novel hybrid conductors based on doped ceria and BCY20 for ITSOFC applications, Electrochemistry communications, 6 (2004) 378-383.

[25] T. Schober, Composites of ceramic high-temperature proton conductors with inorganic compounds, Electrochemical and Solid-State Letters, 8 (2005) A199-A200.

[26] X. Li, N. Xu, L. Zhang, K. Huang, Combining proton conductor BaZr0.8Y0.2O3- $\delta$ with carbonate: Promoted densification and enhanced proton conductivity, Electrochemistry Communications, 13 (2011) 694-697.

[27] L. Zhang, R. Lan, A. Kraft, S.W. Tao, A stable intermediate temperature fuel cell based on doped-ceria-carbonate composite electrolyte and perovskite cathode, Electrochemistry Communications, 13 (2011) 582-585.

[28] L. Zhang, R. Lan, C.T.G. Petit, S.W. Tao, Durability study of an intermediate temperature fuel cell based on an oxide-carbonate composite electrolyte, International Journal of Hydrogen Energy, 35 (2010) 6934-6940.

[29] R. Raze, X.D. Wang, Y. Ma, Y.Z. Huang, B. Zhu, Enhancement of conductivity in ceria-carbonate nanocomposites for LTSOFCs, Journal of Nano Research, 6 (2009) 197-203.

[30] D. Lubben, F. Modine, Enhanced ionic conduction mechanisms at LiI $/ \mathrm{Al}<\mathrm{inf}>2</ \mathrm{inf}>\mathrm{O}<\mathrm{inf}>$ $3</$ inf $>$ interfaces, Journal of applied physics, 80 (1996) 5150-5157.

[31] A. Larson, R. Von Dreele, General Structure Analysis System (GSAS)(Report LAUR 86-748), New Mexico: Los Alamos National Laboratory, (2004).

[32] S.W. Tao, J.T.S. Irvine, Study on the structural and electrical properties of the double perovskite oxide SrMn0.5Nb0.5O3-delta, J. Mater. Chem., 12 (2002) 2356-2360.

[33] S. Zha, J. Cheng, Q. Fu, G. Meng, Ceramic fuel cells based on ceria-carbonate salt composite electrolyte, Materials chemistry and physics, 77 (2003) 594-597. 


\section{Captions}

Table 1 Structure parameters of $\mathrm{SrFe}_{0.7} \mathrm{Mn}_{0.2} \mathrm{Mo}_{0.1} \mathrm{O}_{3-\delta}$.

Fig. 1 XRD of pattern of $\mathrm{BaCe}_{0.5} \mathrm{Zr}_{0.3} \mathrm{Y}_{0.16} \mathrm{Zn}_{0.04} \mathrm{O}_{3-\delta} \quad(\mathrm{BCZYZn})$ (a) and BCZYZn-carbonate composite after fuel cell test (b).

Fig. 2 Temperature dependence of conductivity of $\mathrm{BaCe}_{0.5} \mathrm{Zr}_{0.3} \mathrm{Y}_{0.16} \mathrm{Zn}_{0.04} \mathrm{O}_{3-\delta}$ $(\mathrm{Li}, \mathrm{Na})_{2} \mathrm{CO}_{3}$ composite in air.

Fig. 3 XRD pattern of $\mathrm{SrFe}_{0.7} \mathrm{Mn}_{0.2} \mathrm{Mo}_{0.1} \mathrm{O}_{3-\delta}$. Data were collected at room temperature from a sample fired at $1300{ }^{\circ} \mathrm{C}$ for 4 hours.

Fig. 4 Temperature dependence of conductivity of $\mathrm{SrFe}_{0.7} \mathrm{Mn}_{0.2} \mathrm{Mo}_{0.1} \mathrm{O}_{3-\delta}$ in air.

Fig. 5 The performance of single cell with $\mathrm{SrFe}_{0.7} \mathrm{Mn}_{0.2} \mathrm{Mo}_{0.1} \mathrm{O}_{3-\delta}$ cathode (a) dependence of cell voltages and power densities on current densities and (b) corresponding impedances.

Fig. 6 The performance of single cell with lithiated NiO cathode (a) dependence of cell voltages and power densities on current densities and (b) corresponding impedances.

Figure 7 The XRD pattern of the SFMMO cathode (a), the SFMMO and BCZYZn mixture after firing at $600{ }^{\circ} \mathrm{C}(\mathrm{b})$, the SFMMO and $(\mathrm{Li}, \mathrm{Na})_{2} \mathrm{CO}_{3}$ mixture after firing at $600{ }^{\circ} \mathrm{C}(\mathrm{c})$. 
Table 1 Structure parameters of $\mathrm{SrFe}_{0.7} \mathrm{Mn}_{0.2} \mathrm{Mo}_{0.1} \mathrm{O}_{3-\delta}$.

\begin{tabular}{|c|c|c|c|c|c|c|}
\hline Atom & Site & Occupancy & $x$ & $y$ & $z$ & $\mathrm{U}_{\text {iso }} / \AA^{2}$ \\
\hline $\mathrm{Sr}$ & $1 \mathrm{a}$ & 1 & 0 & 0 & 0 & $0.0105(10)$ \\
\hline $\mathrm{Fe}$ & $1 \mathrm{~b}$ & 0.7 & 0.5 & 0.5 & 0.5 & $0.0063(13)$ \\
\hline $\mathrm{Mn}$ & $1 \mathrm{~b}$ & 0.2 & 0.5 & 0.5 & 0.5 & $0.0063(13)$ \\
\hline $\mathrm{Mo}$ & $1 \mathrm{~b}$ & 0.1 & 0.5 & 0.5 & 0.5 & $0.0063(13)$ \\
\hline $\mathrm{O}$ & $3 \mathrm{c}$ & $0.97(2)$ & 0 & 0.5 & 0.5 & $0.011(4)$ \\
\hline
\end{tabular}

Note: Space group $\operatorname{Pm} \overline{3} \mathrm{~m}(221) ; \mathrm{a}=3.8790(1) \AA \AA^{\prime}, \mathrm{V}=58.364(1) \AA^{3} \cdot \mathrm{R}_{\mathrm{wp}}=9.21 \%, \mathrm{R}_{\mathrm{p}}$ $=6.38 \%, \chi_{\mathrm{red}^{2}}=3.212$. 


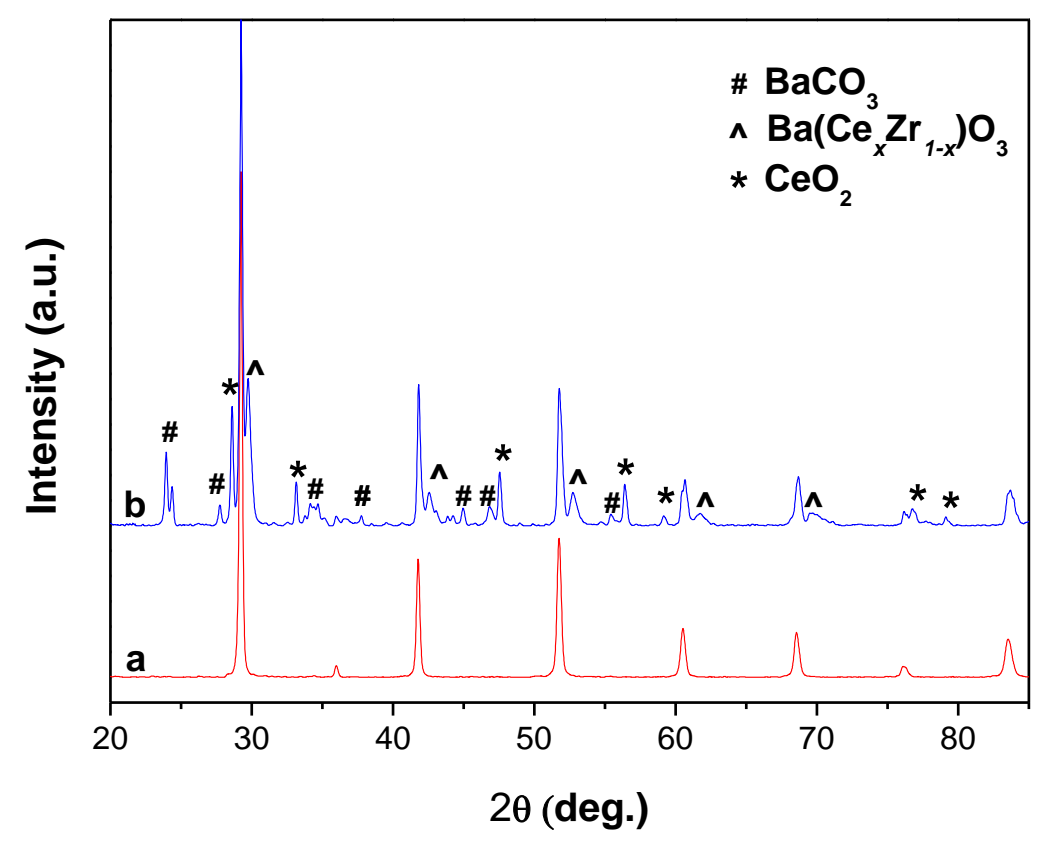

Fig. 1 XRD of pattern of $\mathrm{BaCe}_{0.5} \mathrm{Zr}_{0.3} \mathrm{Y}_{0.16} \mathrm{Zn}_{0.04} \mathrm{O}_{3-\delta} \quad(\mathrm{BCZYZn}) \quad$ (a) and BCZYZn-carbonate composite after fuel cell test (b). 


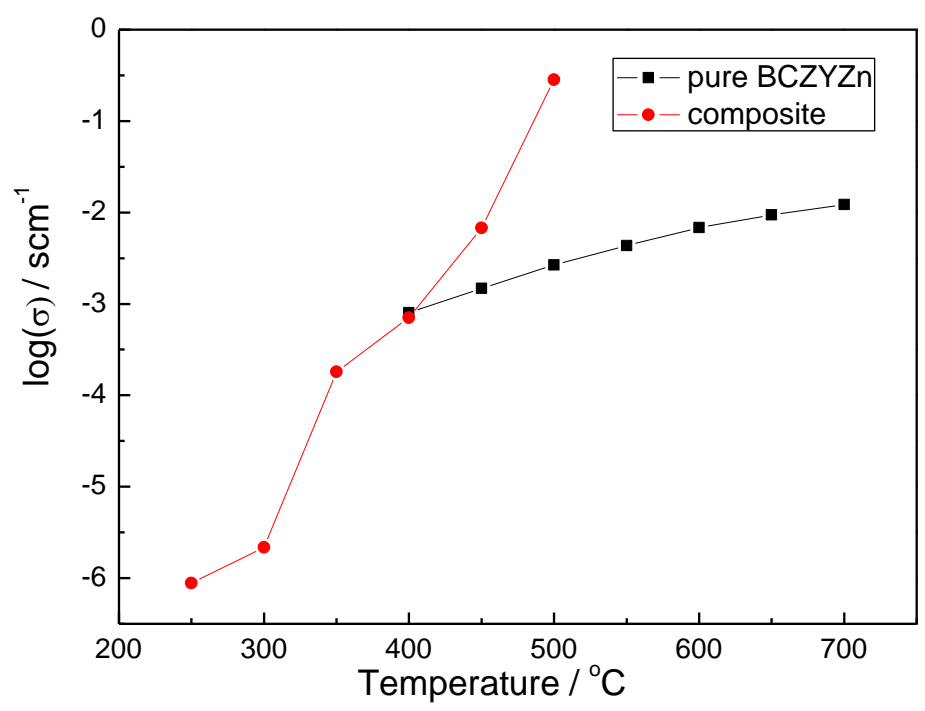

Fig. 2 Temperature dependence of conductivity of pure $\mathrm{BaCe}_{0.5} \mathrm{Zr}_{0.3} \mathrm{Y}_{0.16} \mathrm{Zn}_{0.04} \mathrm{O}_{3-\delta}$ and $\mathrm{BaCe}_{0.5} \mathrm{Zr}_{0.3} \mathrm{Y}_{0.16} \mathrm{Zn}_{0.04} \mathrm{O}_{3-\delta}-(\mathrm{Li}, \mathrm{Na})_{2} \mathrm{CO}_{3}$ composite in air. 


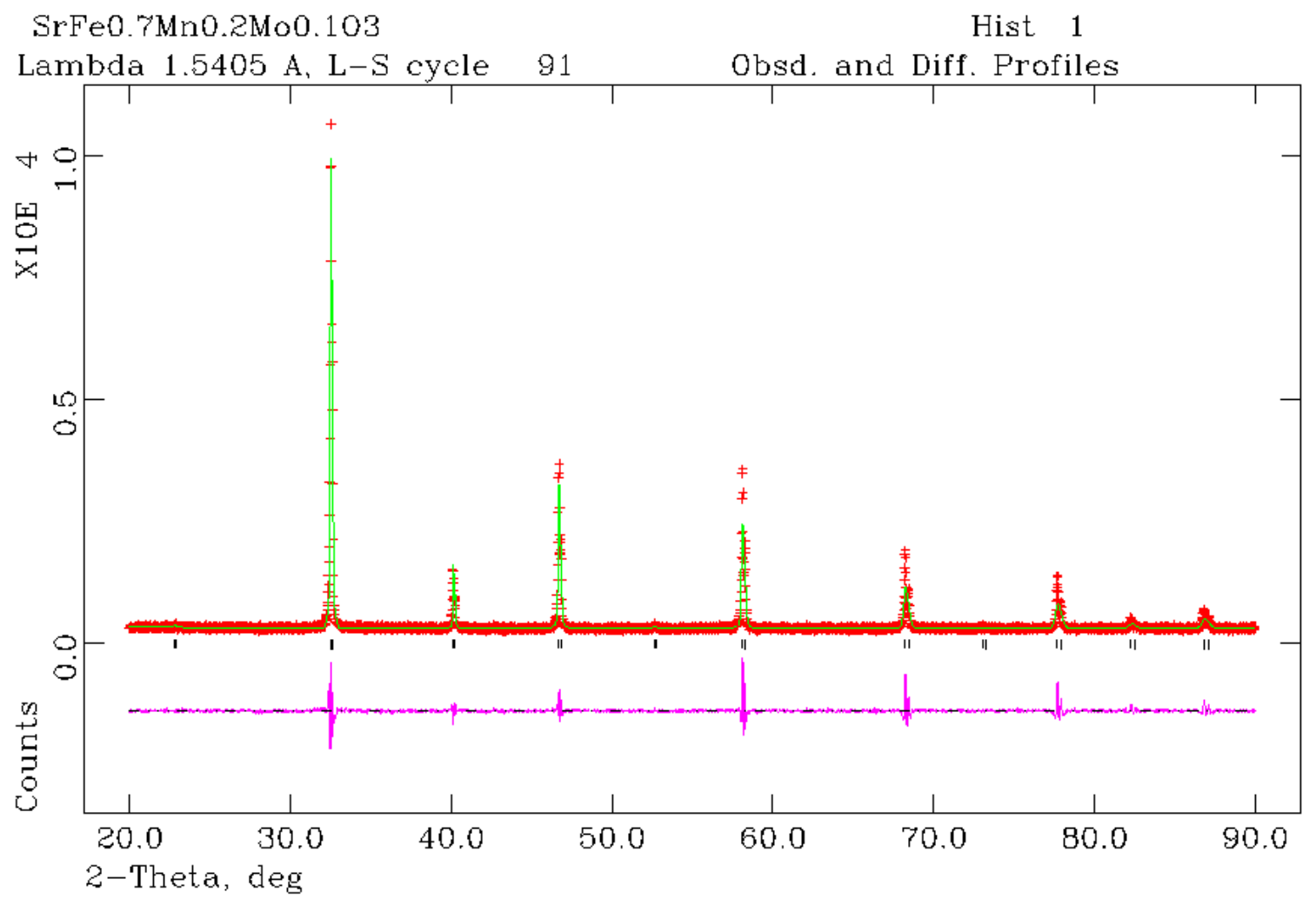

Fig. 3 XRD pattern of $\mathrm{SrFe}_{0.7} \mathrm{Mn}_{0.2} \mathrm{Moo}_{0.1} \mathrm{O}_{3-\delta}$. Data were collected at room temperature from a sample fired at $1300{ }^{\circ} \mathrm{C}$ for 4 hours. 


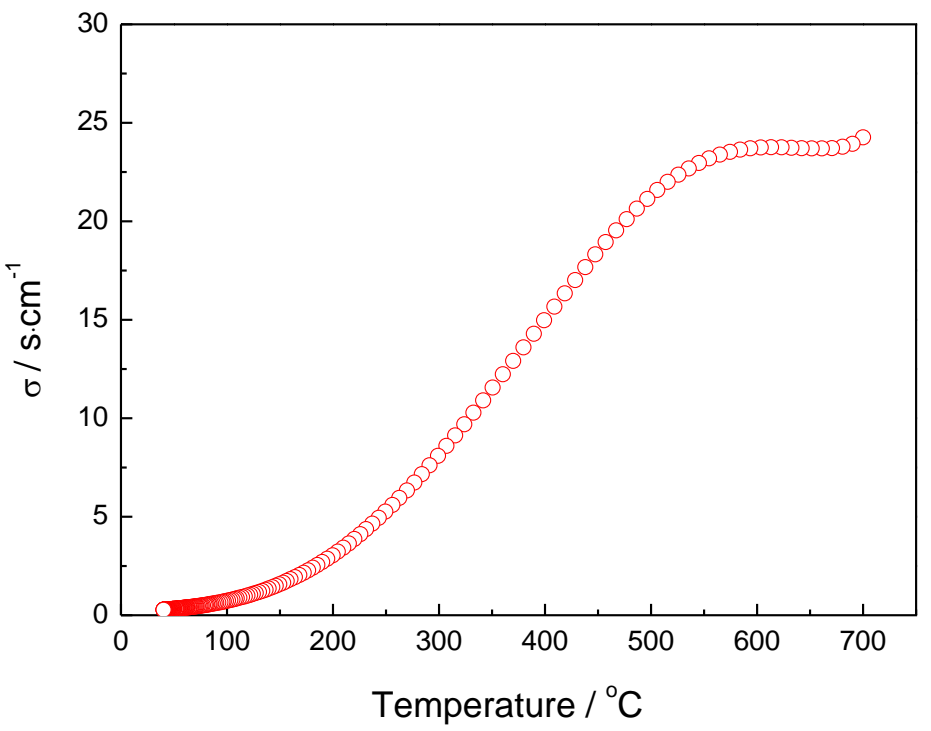

Fig. 4 Temperature dependence of conductivity of $\mathrm{SrFe} 0.7 \mathrm{Mn} 0.2 \mathrm{Mo} 0.1 \mathrm{O} 3-\delta$ in air. 

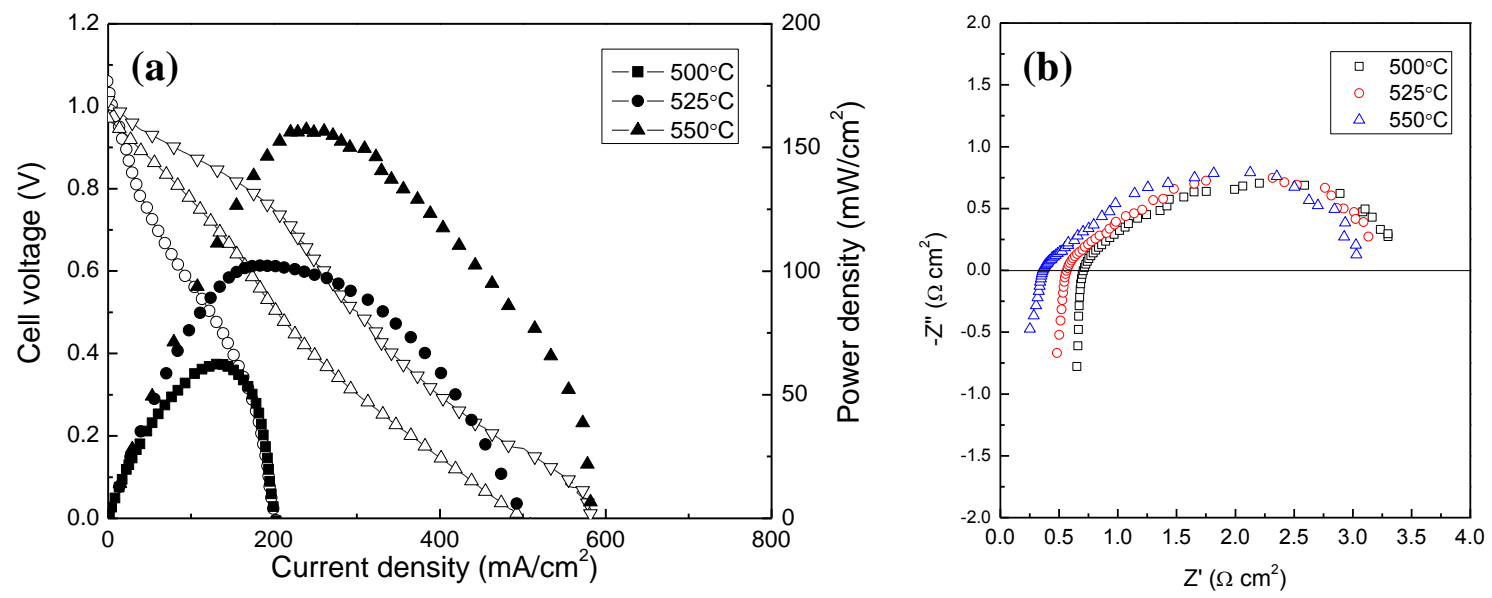

Fig. 5 The performance of single cell with $\mathrm{SrFe}_{0.7} \mathrm{Mn}_{0.2} \mathrm{Mo}_{0.1} \mathrm{O}_{3-\delta}$ cathode (a) dependence of cell voltages and power densities on current densities and (b) corresponding impedances. 

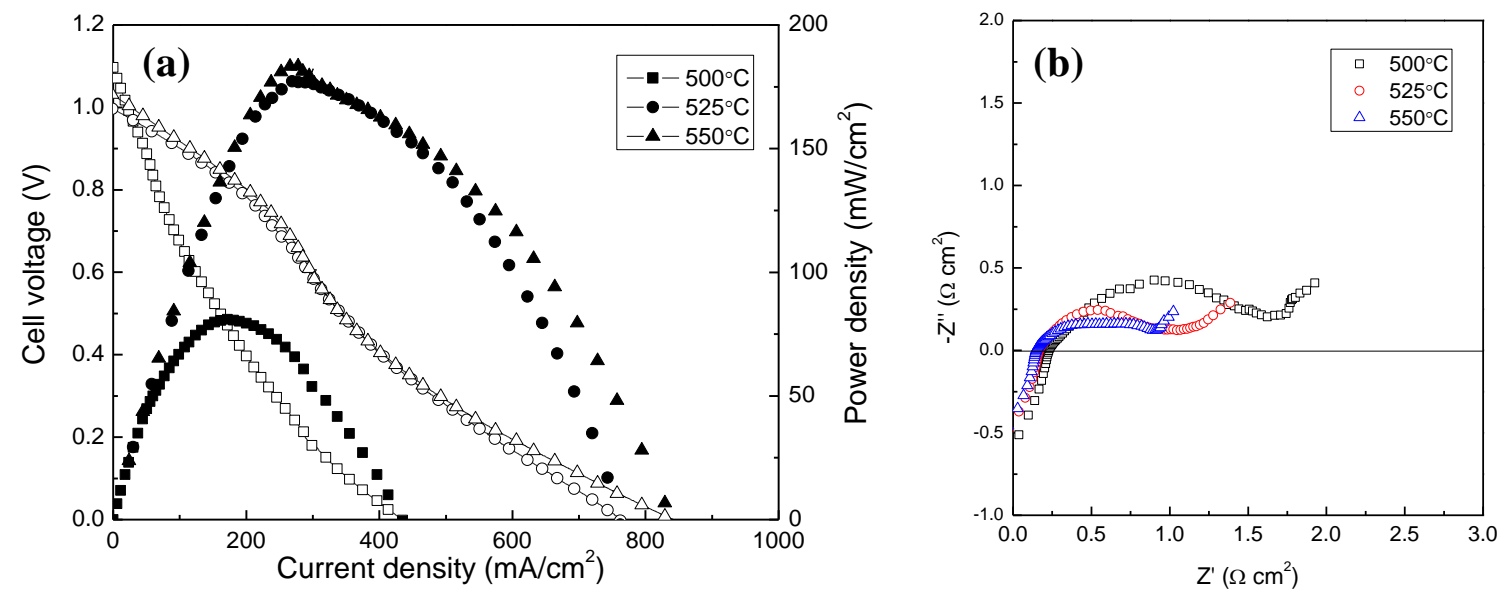

Fig. 6 The performance of single cell with lithiated $\mathrm{NiO}$ cathode (a) dependence of cell voltages and power densities on current densities and (b) corresponding impedances. 


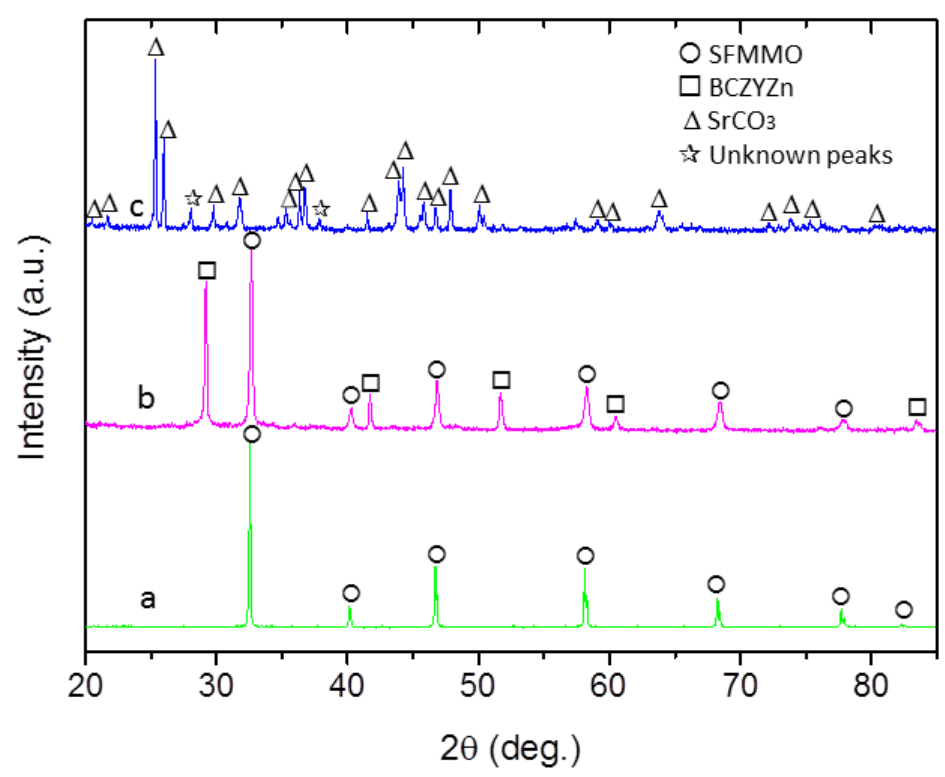

Figure 7 The XRD pattern of the SFMMO cathode (a), the SFMMO and BCZYZn mixture after firing at $600{ }^{\circ} \mathrm{C}(\mathrm{b})$, the $\mathrm{SFMMO}$ and $(\mathrm{Li}, \mathrm{Na})_{2} \mathrm{CO}_{3}$ mixture after firing at $600{ }^{\circ} \mathrm{C}(\mathrm{c})$. 